\title{
Effects of cotton seed oil sludge on the performance and carcass characteristics of young rabbits
}

\author{
G. S. Bawa, M. Orunmuyi and O. Odelewo \\ Department of Animal Science, Ahmadu Bello University, Zaria, Nigeria.
}

\begin{abstract}
A feeding trial lasting 63 days was conducted using 60 weaned rabbits of mixed sexes and breeds with an average initial live weight of $487.50 \mathrm{~g}$. The rabbits were allotted to 5 dietary treatments of 12 replicates each. Cotton seed oil sludge (CSOS) was included at $0,3,6,9$ and $12 \%$ levels of the experimental diets respectively. The diets were isonitrogenous $(20 \% \mathrm{CP})$. The results showed that feed intake, weight gain and feed efficiency were significantly different $(P<0.05)$ across the dietary treatments. The highest weight gain was observed on rabbits fed diet containing $12 \%$ level of cotton seed oil sludge (CSOS). The use of cotton seed oil sludge in rabbit diet was cost effective. The percentage reduction in feed cost per kilogram of diet for the 3,6,9 and $12 \%$ level of inclusion were $2.90,6.43,12.04$ and $15.25 \%$ respectively. The dressing percentage and percent belly fat increased significantly $(\mathrm{P}<0.05)$ with increase in the level of cotton seed oil sludge. A non-significant but slight increase was observed with the carcass weight and weight of the major organs $(P>0.05)$ as the level of cotton seed oil sludge increased in the diet. It was concluded that cotton seed oil sludge (CSOS) can be included up to $12 \%$ level in the diets of young rabbits without adverse effects on performance and carcass characteristics.
\end{abstract}

Key words: Cotton seed, oil sludge, young rabbits, carcass, performance.

\section{Introduction}

The domestic rabbit is one of the animal species with high potential for filling the gap between the demand and supply of animal protein in developing countries like Nigeria. This is because of its high genetic potential, short generation interval, high fecundity, rapid growth rate, high prolificacy and relatively low cost of production (Oyawoye, 1989). However, one of the major problem affecting the rabbit industry is the chronic shortage of feeds and fodder especially during the dry season (Vasanthakumar et al, 1999). Feed accounts for $70-80 \%$ of the total cost of production in rabbit farming (Gowda et al. 1998).
In developing countries of the tropics, the conventional energy feedstuffs such as cassava, maize, guinea corn and millet are not only scarce but expensive. In addition, they constitute a major regular source of food for humans. There is therefore the need to source for cheaper alternative energy sources for optimum rabbit production. One of such energy supplement is cotton seed oil shudge. Cotton seed oil sludge is primarily oil and is obtained as a result of screw -pressing cotton seed to extract oil for human consumption. Apart from using it locally for soap making, it is still an industrial waste. Unlike palm oil, ground nut oil and cotton seed oil, it is not widely used as cooking oil in human diets. It is very cheap and there is high potential of having 
surplus cotton seed oil sludge for inclusion into livestock diets. Presently, cotton is one of the major cash crop in the Northern part of Nigeria where so many cotton seed oil mills are located. Each of the mills has a crushing capacity of 989,000 metric tons. Work on the use of cotton seed oil sludge in livestock diets is still scanty. This study was therefore designed to assess the potential of cotton seed oil sludge as an energy source in the diets of young rabbits.

\section{Materials and Methods}

\section{Location of Experiment}

The experiment was conducted at the rabbitry unit of the Ahmadu Bello University, Teaching and Research Farm, Zaria. Zaria is located in the Northern Guinea Savanna Zone of Nigeria with an altitude of $610 \mathrm{~mm}$.

\section{Source of Cotton Seed Oil Sludge}

The cotton seed cil sludge used for this study was obtained as an industrial waste product of Sun Seed Oil Mill Company Nigeria Limited, Zaria along Zaria - Jos road, Nigeria. It is a by-product of screw-pressing cotton seed to extract oil for human consumption.

\section{Experimental Diets}

Five experimental diets were formulated as shown in Table 1. Diet 1 was a maize - soybean control diet while diets $2,3,4$ and 5 contained cotton seed oil sludge included at 3,6,9 and $12 \%$ levels of the diets respectively.

Experimental Animals and their Management Sixty weaned rabbits of mixed breeds (New Zealand white, California and Dutch) and sexes with an average initial weight of $487.50 \mathrm{~g}$ were randomly allotted to five groups of twelve animals per group in a complete randomize design. Prior to the experiment, each of the rabbits was given $0.2 \mathrm{mls}$ of ivomec intra muscular against ecto and endoparasites.
The rabbits were housed individually in an all wire cage $(40 \times 40 \times 60 \mathrm{~cm})$ located in an opensided building. Each of the individual cages was well equipped with watering and feeding facilities. The animals were individually fed with weighed quantities of feed twice daily at 8.00 and 16.00 hours and had unrestricted access to water. Refused or wasted feed was collected daily, airdried and weighed. Rabbits were weighed weekly and feed intake, live-weight and feed intake per unit gain were determined. The experiment lasted for 63 days.

\section{Carcass Evaluation}

At the end of the feeding trial, five rabbits whose weights were close to the mean weight of rabbits on each experimental diets were selected and starved overnight to clear the guts. Live weights were recorded before stunning and sacrificing by cutting the jugular vein. The tail was cut very close to the base before removing the pelt after removing the head and feet. Evisceration of the rabbit carcasses were carried out and all internal organs were weighed separately and expressed as percentage of dressed carcass weight. The weights and lengths of the components of the gasiro-intestinal tracts (GIT) were also taken. The carcasses were then divided into primal parts. Each part was expressed as a percentage of the dressed carcass.

\section{Analytical Procedures}

Proximate analysis of the experimental diets were carricd out using the method of AOAC (1990) as presented in Table 2. All data generated from the study were subjected to analysis of variance employing a complete randomized design as described by Steel and Torrie (1980) and where statistical significance were observed, the means were compared using the Duncan's Multiple Range Test according to SAS (1995). 
Table 1 Compositions of the experimental diets

Graded levels of cotton seed oil

\begin{tabular}{|c|c|c|c|c|c|}
\hline \multirow[b]{2}{*}{ Ingredient } & \multicolumn{2}{|c|}{ sludge $\%$} & \multirow{2}{*}{6} & \multirow[b]{2}{*}{9} & \multirow{2}{*}{12} \\
\hline & $\mathbf{0}$ & 3 & & & \\
\hline $\begin{array}{l}\text { Maize } \\
\text { Soyabean }\end{array}$ & 46.65 & 43.35 & 39.09 & 35.29 & 31.33 \\
\hline & 39.90 & 39.22 & 40.46 & 61.26 & 42.22 \\
\hline $\begin{array}{l}\text { Maize Offal } \\
\text { Cotton seed oil sludge }\end{array}$ & 10.00 & 10.00 & 10.00 & 10.00 & 10.00 \\
\hline $\begin{array}{l}\text { Cotton seed oil sludge } \\
\text { Bone meal }\end{array}$ & 0.00 & 3.00 & 6.00 & 9.00 & 12.00 \\
\hline $\begin{array}{l}\text { Bone meal } \\
\text { Limestone }\end{array}$ & 2.50 & 2.50 & 2.50 & 2.50 & 2.50 \\
\hline & 1.00 & 1.00 & 1.00 & 1.00 & 1.00 \\
\hline $\begin{array}{l}\text { Vitamin - Mineral Premix* } \\
\text { Sait }\end{array}$ & 0.20 & 0.20 & 0.20 & 0.20 & 0.20 \\
\hline$\frac{\text { Sait }}{\text { Total }}$ & 0.35 & 0.35 & 0.35 & 0.35 & 0.35 \\
\hline & 100.00 & 100.00 & 100.00 & 100.00 & 100.00 \\
\hline \multicolumn{6}{|l|}{ Calculated Analysis } \\
\hline C.P\% & 20.00 & 20.00 & 20.00 & 20.00 & 20.00 \\
\hline $\begin{array}{l}\text { Metabolizable Energy, } \\
\text { (ME KCal } / \mathrm{kg})\end{array}$ & 3164.70 & 3284.10 & 3400.80 & 3518.9 & 3636.7 \\
\hline Calcium (Ca) \% & 1.39 & 1.39 & 1.39 & 1. 389 & 1.392 \\
\hline Phosphorus (P) \% & 0.78 & 0.78 & 0.78 & 0.76 & 0.76 \\
\hline $\mathrm{Ca}: \mathrm{P} \%$ & 1. 77 & 1.79 & 1.804 & 1.82 & 1.84 \\
\hline$M$ ethionine ( $M$ eth) $\%$ & 0.51 & 0.50 & 0.501 & 0.49 & 0.43 \\
\hline Cysteine (Cyst) \% & 0.28 .5 & 0.281 & 0.281 & 0.280 & 0.278 \\
\hline $\mathrm{Meth}+\mathrm{Cyst} \%$ & 0.793 & 0.784 & 0.782 & 0.777 & 0.706 \\
\hline Crude fiber $(C \cap) \%$ & 4.23 & 4.18 & 4.13 & 407 & 4.01 \\
\hline Cost/Kg diet (N) & 28.32 & 27.50 & 26.70 & 24.91 & 24.00 \\
\hline
\end{tabular}

Cost $/ \mathrm{K}$ g diet $(\mathrm{N})$ tollowing per kg of diet

Vitamin A, 12,000 I. U; Vitamin D, 1, 2000 I. U; Vitamin E, $3.6 \mathrm{U}$; Vitamin K, $1.8 \mathrm{mg}$; Vitamin B $3.6 \mathrm{mg}$; Nicotinate, $18 \mathrm{mg}$; Calcium-d-Pantothenate, $9.6 \mathrm{mg}$; Biotin, $0.36 \mathrm{mg}$; Vitamin B $12,0.012 \mathrm{mg}$; Choline chloride, $120 \mathrm{mg}$; Chlotetracycline, $4.8 \mathrm{mg}$; Manganese, $24 \mathrm{mg}$; Iron $48 \mathrm{mg}$ : Zinc, $96 \mathrm{mg}$; Copper $60 \mathrm{mg}$; lodine $1.8 \mathrm{mg}$ : Cobalt, $48 \mathrm{mg}$.

Table 2 Proximate composition of the experimental diets

\begin{tabular}{|c|c|c|c|c|c|}
\hline \multirow[b]{2}{*}{ Parameter } & \multicolumn{5}{|c|}{ Graded levels of } \\
\hline & 0 & 3 & 6 & 9 & 12 \\
\hline Dry matter $\%$ & 92.31 & 92.08 & 92.34 & 92.48 & $\overline{93.46}$ \\
\hline Crude protein $\%$ & 20.56 & 21.10 & 20.75 & 20.72 & 20.34 \\
\hline Crude tiber \% & 6.29 & 6.26 & 6.05 & 6.83 & 6.78 \\
\hline $\mathrm{Oil} \%$ & 4.48 & 4.55 & 4.76 & 4.85 & 5.35 \\
\hline Ash $\%$ & 6.23 & 6.10 & 6.65 & 7.12 & 7.24 \\
\hline N.F.E. \% & 62.44 & 62.59 & 62.79 & 63.78 & 63.41 \\
\hline
\end{tabular}

\section{Results}

The results of the performance of rabbits fed the experimental diets are presented in Table 3 . The final live weight of the animals increased as the level of the cotton seed oil sludge increased in the diets. The difference across the dietary treatments were however not statistically significant $(P>0.05)$. The feed intake was not affected by the level of dietary treatments $(\mathrm{P}>$
0.05 ). The amount of feed consumed however decreased slightly as the level of cotton seed oil sludge increased in the diets. The average daily weight gain differed significantly $(P<0.05)$ across the dietary treatments. The rabbits gain more weight as the dietary level of cotton seed oil sludge increased. Rabbits fed Diets 2, 3,4 and 5 utilized their feed efficiently as those fed the control diet. The cost per $\mathrm{Kg}$ gain decreased 
Table 3 Effects of graded levels of cotton seed oil sludge on carcass characteristics of young rabbits

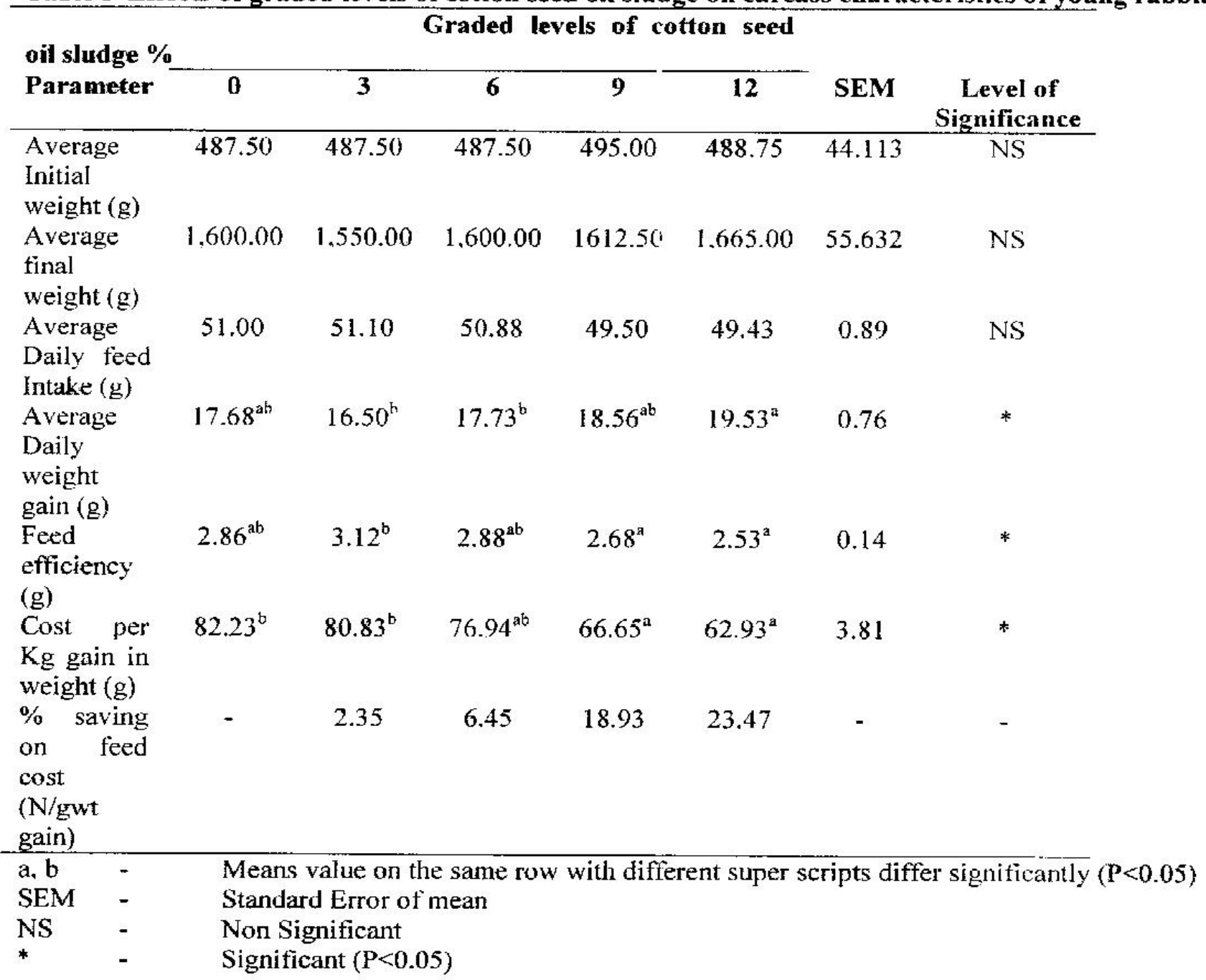

significantly as the level of cotton seed oil sludge increased from 6 to $12 \%$. Results of the carcass characteristics of the experimental animals fed the dietary treatments are presented in Table 4. The pre slaughter weight, carcass weight and intestinal length were not significantly affected by the dietary treatments. The dressing percentage of the animais were significantly improved $(P<0.05)$ with increase in the level of dietary cotton seed oil sludge. The belly fat and kidney expressed as the percent of carcass weight increased significantly $(P<0.05)$ as the level of oil sludge increased in the diet.

\section{Discussion}

Generally, the performance of the rabbits fed cotton seed oil sludge in this study has shown that the use of cotton seed oil sludge in monogastric diets could have some beneficial effects. Feed intake was not adversely affected as the level of cotton seed oil increased in the diets. This suggest the absence of odour and toxic factors in cotton seed oil sludge unlike that reported by Fajimi et al, (1993) with rubber seed 
Bawa, Orunmuyi and Odelewo

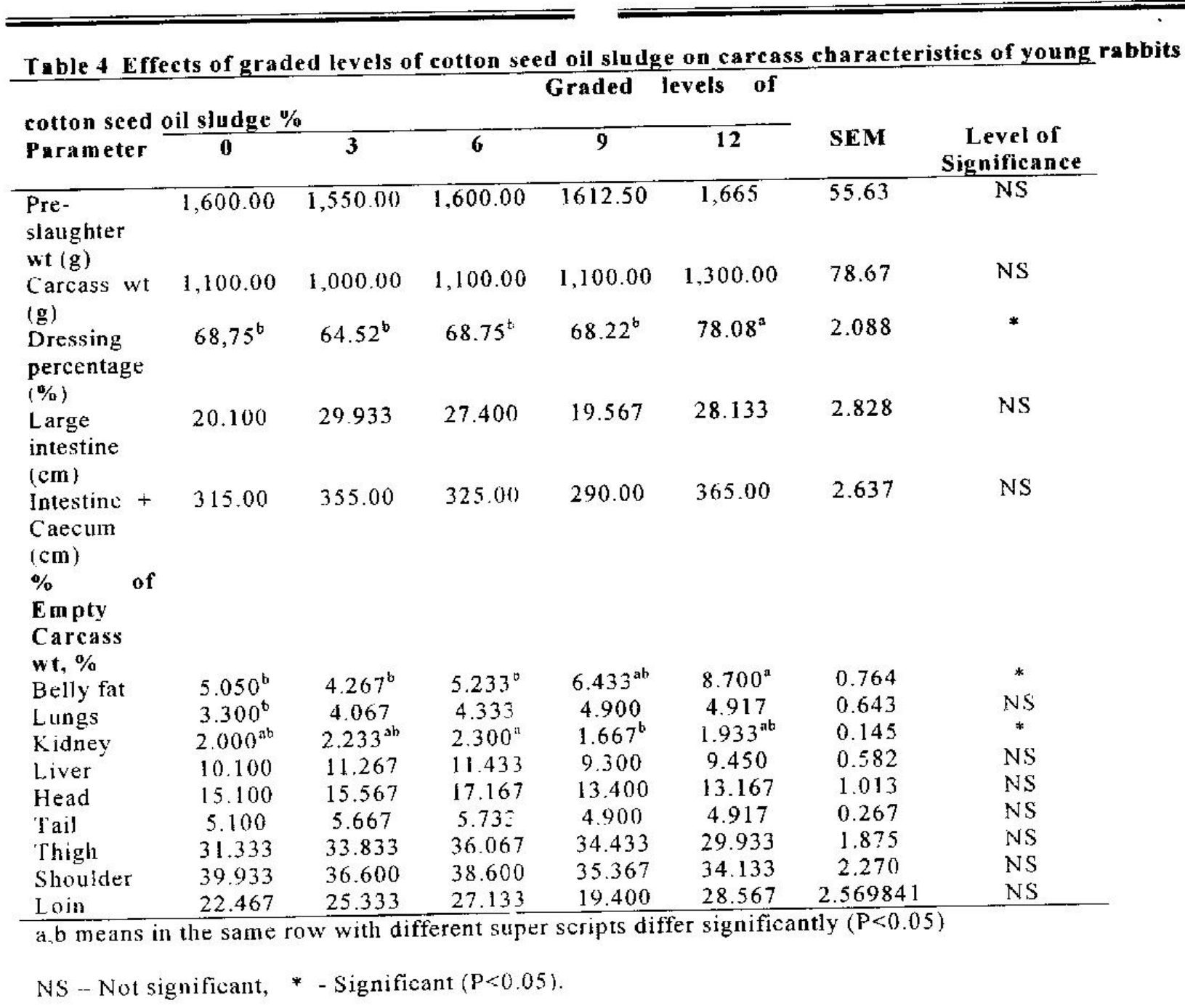

oil, and Adeyemi (1998) with thevetia oil. However, the slight reduction in feed consumption of rabbits fed the cotton seed oil sludge could be related to increase in energy density of the diets due to oil inclusion (Odunsi and Gbadamosi 2001). Monogastric animals are expected to consume less of high energy diet in attempt not to overshoot their energy requircments. In the present trial the caloric density of the diets increased as the level of the dietary oil increase (Table 1). A similar report by Aduku and Nuhu (1996) on broilers fed diets containing oil sludge showed a slight but non significant $(\mathrm{P}>0.05)$ decrease in feed intake as the dietary oil level increased. Longe and Adekoya (1988) had earlier observed that addition of oil to a diet that is otherwise adequate in energy, lowers feed intake.

The trend of the daily weight gain result showed a tendency towards improved weight gain with cotton seed oil sludge supplementation. Oils and fat generally have been found to enhance growth by improving the utilization of the dietary nutrients (Mairorino et al, 1986). Fats and oil slow down the rate of passage of diet through the digestive tract which would allow longer contact with the digestive enzymes and possibly 
microorganisms necessary for fermentation of indigestible fraction of feed like the fiber. The improved weight gain of rabbits fed diets containing 9 and $12 \%$ cotton seed oil sludge compared to the control diet supported earlier reports of Ibiyo and Atteh (2005). These authors attributed the improvement in weight gain of birds fed diets with supplemental palm oil relative to those without to the extra caloric effect of fat accompanied with a reduced passage time in the gastro intestinal tract. The trend of increase in weight gain as the level of cotton seed oil sludge increased was also similar to the report of Yeing and Markharjee (1984) who observed a higher weight gain and feed efficiency for chicken fed 9 or $12 \%$ palm oil than those on $6 \%$ palm oil diet. The final live weight result followed a similar trend with that of the daily weight gain.

Inciusion of oils at 9 and $12 \%$ resulted in a slightly better feed efficiency than for rabbits in $3 \%$ cotton seed oil sludge diets. This supported the views of Adeyemi (1998) and Freeman (1983) that "oils generally improved feed conversion ratio. Sell et al (1979) had earlier observed improved feed efficiency by added fat. The earlier reports by Aduku and Nuhu (1996) that cotton seed oil sludge can be utilized at levels up to $12.5 \%$ without any adverse effect on the efficiency of feed utilization of broilers was aiso confirmed in this study.

There was cost savings associated with the use of cotton seed oil sludge in diets of rabbits. The use of cotton seed oil sludge resulted in potential savings of $\mathrm{N} 0.82, \mathrm{~N} 1.62, \mathrm{~N} 3.41$ and $\mathrm{N} 4.32 \mathrm{per} \mathrm{Kg}$ feed for the $3,6,9$ and $12 \%$ cotton seed oil sludge diets, respectively. This amount to savings of $\mathrm{N} 820.00, \mathrm{~N} 1,620.00, \mathrm{~N} 3,410.00$ and $\mathrm{N} 4,320.00$ per tonne of feed for the 3,6,9 and $12 \%$ cotton seed oil sludge diets respectively. The cost of producing a unit of weight gain in the rabbits decreased significantly $(\mathrm{P}<0.05)$ with increase in the level of dietary oil sludge. The decrease in the cost per $\mathrm{Kg}$ of diet (Table 1) as the level of oil sludge increased in the diet might be responsible for the significant lowering of the cost per $\mathrm{Kg}$ gain in weight.

The significant increase up to $12 \%(\mathrm{P}<0.05)$ in the dressing percentage as the level of oil sludge ncreased up to $12 \%$ in the diet could be a reflection of the increase in efficiency and utilization of the diet to yield more carcasses as he level of oil sludge increased in the diet. The significant increase $(P<0.05)$ in belly fat expressed as percentage of the carcass weight as the ievel of oil sludge increased in the diet is expected. Usually excess energy and fat in the body are stored in form of fat around the belly and some inajor organs in the body. The slight but nonsignificant increase in carcass weight with ncrease in the level of oil sludge also supported the results of (Iyeghe - Erakpotobor et al 2000). These authors used palm oil at 0.3 and $5 \%$ in liets of rabbits and observed a non-significant ncrease in the percent carcass nd organ weighis of growing rabbits as the tevel of palm oil increased from 3 to $5 \%$. lyayi and Ngodigha (1991) also reported a non-signilicant increase in the liver, kidney and heart weights of rabbits fed graded levels of palm oil.

\section{Conclusion}

The results of this study have shown that cotton seed oil sludge up to $12 \%$ level of inclusion in diets can be adequately utilized by rabbits and can successfully reduce the amount of maize in a practical rabbit diet without adverse effect on performance and carcass characteristics. As an industrial waste, its incorporation in monogastric diets as a feed ingredient especially for large scale operations would results in substantial cost savings. 


\section{References}

Adeyemi, O.A. 1998. Response of tinishing broilers to graded levels of heat treated solvent extracted thevetia oil. Nig. $J$. Anim. Prod. 25:134 - 138.

Aduku, A.O. and I. Nuhu 1996. A conparative evaluation of cottonseed oil sludge and palm oil in broiler diets. Trop. Agric (Trinidad). Vol. 73. (3): 206-210.

Fajimi,A.O., Babatunde, G.M. Ogunlena, F.F. and A. Oyejide, 1993. Comparative utilization of rubber seed oil and palm oil by broilers in a humid tropical environment. Anim. Feed Sci Tech. 43: $177-188$

Fetuga, B.L. and O. Ogunfowora 1476. The supply and utilization of some major oil seeds cakes in Nigeria. Nig. J. Anim. Prod. 3(2), Pp45-52

Freeman, C.P. 1983. Fat supplementation in animal production - Monogastric animals. Proc. Nutrition Society. 42: $357-354$.

Gowda, S.K., R.C. Katiyar, A.K. Sharma and V.R.B. Sastry 1996. Blood Biochemical profile and histopathology of vital organs in rabbits fed processed neem kernel meal incorporatcd diets. Asian Aus. J. Anim. Sc. 10(4): 398-401.

Ibiyo, L.M.O. and J. O. Atteh 2005. Response of starter broilers to diets cortaining graded levels of rice bran with or without palm oil. Nig. J. Anim Prod. 32: $39-45$.

lyayi, E.A. and E. Ngodigha, 1991. Performance and organ weights of rabbits fed diets with graded levels of cassava peels and paim oil. J.Appl. Rabobit. Res.14:152-154

Iyeghe-Erakpotobor G.T. Ekpeyong, T.E and R. O. Balogun. 2000. Effects of palm oil supplementation on carcass yield and fatty acid composition of growing rabbits. Nig. J Anim. Prod 27 (1) 29 33.

Longe, O.G. and O.E. Adekoya 1988. Response of laying hens to different inclusion levels of palm kemel meal and vegetable oil. Nig. J. Anim. Prod 15:111-117.

Maiorino, R.M., Hozab, A.A., Mitchell, R and B.L. Reid, 1986. Animal fat effects on Nutrient utilization. Poulity Sci. $65: 2304$ -2313 .

Odunsi, A.A. and A. J. Gbadamosi, 2001. Effects of dietary inclusion of palm oil and sheabutter fat on growth and sexual maturity of pullets. Nig. J. of Anim. Prod. 28(1): $26-30$.

Oyawoye, E.O. 1989. Rabbit production as a means of supplying cheap Animal protein in Nigeria. A journal of National Veterinary Research Institute, National Agricultural Extension Research and Liaison Services and National Animal Production Research Inst. Vol.9: 1 - 4.

SAS 1995. Statistical Analysis system, Institute Inc. Users' Guide. Statistic version 6 ed. Carry, North Carolina, L.S.A.

Steel R. G. D. and J.H. Torrie 1980. Principles and Procedures of statistics. A Biometrics approach $2^{\text {nd }} e d$. McGraw Hill Book Inc., New York. 
Vansanthakumar, P. Sharma L, Sastry V.R.B and S. Kuman 1999. Effects of Graded dietary levels of neem (Azadirachta Indica) seed kernel cake on carcass characteristics of broiler rabbits. Experimental report. Animal Nutrition Division, IURI, Izantnazar; India.
Yeing, S.W. and T.K. Markerjee, 1984. The effect of palm oil supplementation in palm kernel cake based diets on the performance of broiler chickens. Nutr. Abst. and Reviews 54(9): 493.

(Keceived 5th July, 2006: Accepted I6th Nov. 2006). 